\title{
LITERATURA Y FICCIÓN CIENTÍFICA: MALESTAR EN LA CULTURA Y BIOPOLÍTICA
}

\author{
Márcio SELIGMANN-SILVA \\ IEL - UNICAMP
}

\begin{abstract}
Apenas la segunda técnica garantizó sus primeras conquistas revolucionarias, y las cuestiones vitales del individuo - amor y muerte- ya exigen nuevas soluciones.

Walter Benjamin ${ }^{1}$
\end{abstract}

$\mathrm{L}$ a literatura durante mucho tiempo fue considerada, desde un punto de vista humanista, como uno de los principales medios de formación de un individuo enfocado hacia la convivencia en una sociedad calcada en la ética. La literatura seríaa, así, parte del estudio y estaría del lado de la razón en la lucha contra la obscuridad, el irracionalismo y a fuerza bruta. Las Letras también serían parte esencial en la construcción y defensa del espíritu, en oposición al sensualismo y a las necesidades corporales. Esa visión de la literatura como algo antes de más nada edificante, sin embargo, está lejos de ser la óptica exclusiva sobre el tema. En primer lugar, porque la propia noción de literatura es relativamente reciente. Ella es una creación del Iluminismo tardío y sobre todo del Romanticismo. Lo interesante es observar cómo en el mismo momento en que se delineó esa visión edificante y pedagógica de la literatura, muchas obras de la época apuntaban justamente hacia una superación de esa visión humanista que reduce a la literatura a un medio «ortopédico». Se trata aquí de la famosa dialéctica entre el conocimiento, o sea, el concepto, y, por otro lado, el mundo de los fenómenos: el concepto siempre llega «demasiado tarde» en la despedida de lo real. Cuando se establece la noción de literatura como medio de formación del individuo moderno y también, no olvidemos, como importante medio de formación y construcción de la nación, a inicios del siglo XIX, las obras literarias cada vez más ya pasaban a explorar justamente el elemento que niega la posibilidad de establecer un concepto monolítico de individuo y, por ende, de nación. Desde entonces, las obras literarias pasaron más y más a explorar la carne sobre la que las letras y el propio espíritu se constituyen. Basta recordar a Sade para convencernos de eso.

${ }^{1}$ Las traducciones de los textos al español pertenecen al autor. 


\section{Pequeña historia de la ascensión de la biopolítica}

Esta literatura carnal, que busca expresar el cuerpo y niega la visión racionalizadora y espiritualista de las letras, es contemporánea de la toma de conciencia del individuo moderno como un sujeto que existe no más a partir de una serie de certezas y de locales, culturales y geográficos, que no se agitan y que garantizan su auto-imagen, como ocurría en el individuo pre-moderno. Ese individuo moderno justamente se ve como la propia negación de la individualidad: él es dividido, vive en el espacio entre los lugares. Él tiene que aprender a localizarse en el mundo, a construir para sí una vivienda para abrigar a su frágil «yo». La literatura para este sujeto moderno es un importante medio de explorar el mundo, de salir de sí para penetrar en sí, en la misma medida en que construye ese frágil «sí mismo». La literatura permite esas expediciones hacia lo desconocido, sobre todo a los dos grandes desconocidos, el mundo, o la esfera pública, y el «yo» y su esfera privada. Estos viajes literarios, de modo aparentemente paradójico, construyen al mismo tiempo el suelo sobre el cual navegan. En ellas, lo imaginario y lo simbólico se unen para crear fragmentos de realidad que los abrigan y eventualmente promueven un bienestar hacia más allá del continuo malestar en el mundo. Esta visión de la literatura la encara como un dispositivo de diseñar y explorar al mismo tiempo el mundo y el «yo».

No por casualidad, ese dispositivo fue establecido después de una profunda modificación de lo que se concebía como el mundo de las Bellas Letras en la época en que las sociedades modernas adentraron en un nuevo modo de vida social y política, a finales del siglo XVIII. El nuevo sujeto que nació entonces, en el ocaso de la visión medieval y pre-moderna del hombre, de la sociedad y de la política, sufría de un terrible vértigo, derivado de la sensación de que la historia había, de repente, arrancado el suelo bajo sus pies. Él sufre de una profunda consciencia de la relatividad de los valores y de aquello que hasta entonces eran consideradas verdades inmovibles. Ese sujeto fracturado pasa a ver en la literatura ( $\mathrm{y}$ en las artes de un modo general) un importante espacio para experimentar y delinear sus límites y su identidad. La literatura abandona el registro clásico del prodesse et delectare (ser útil y divertir) para tornarse una técnica, o sea un instrumento y una extensión del sujeto, en su lucha para construir un espacio en el mundo.

Lo que me importa en este texto es pensar en qué medida podemos aprender a leer ese nuevo espacio literario, en la medida en que actúa como una especie de frontera móvil entre la esfera pública y la privada (ambas profundamente agitadas en esta época), como un archivo de inscripciones de este proceso de construcción del individuo moderno. Aquí ya podemos vislumbrar lo que significa eso que he denominado como contenido testimonial de la literatura (y de todo documento de cultura). La posibilidad misma de ver al campo literario como un archivo de inscripciones sólo se puede configurar después que el individuo abandonó la vivienda en la cual las certezas ontológicas le garantizaban un sentimiento de pertenencia al mundo. Hasta entonces la literatura y las artes eran vistas como momentos plenamente destacables e aislados de la vida cotidiana. Eran encaradas como productos de ciertas mentes privilegiadas y del ingenio de grandes artistas. A partir del Romanticismo la literatura

y las artes pasan a ser vistas como una parte al mismo tiempo esencial de la cultura y de este nuevo hombre, como también son depreciadas como una excrecencia, teniendo en vista la paulatina 
omnipresencia del modo de pensar economicista y por lo tanto, centrado en el utilitarismo. Este estatuto ambiguo de las artes es análogo a la propia autoimagen de este nuevo hombre prometeico y fáustico, que quiere competir con Dios pero al mismo tiempo se siente desabrigado y frágil, reducido a la inmanencia de su cuerpo.

Con Hannah Arendt, podemos ver ese momento, el final del siglo XVIII, como coincidiendo con el triunfo de la necesidad y de la política como una técnica de vender (más que generar) la utópica felicidad (Arendt, 1988, 2008). La política se resume cada vez más en aquello que antes era parte sólo de la pequeña esfera doméstica y privada: el mantenimiento de la vida con su eterno ciclo de producir y consumir (2008: 144ss.). El parámetro para juzgar la acción política sigue cada vez más una lógica del mantenimiento y reproducción de la vida, se trata de una biológica, o, según Agamben, de una lógica de la zoe, la vida desprovista de organización, que pasó a dominar la acción política. Arendt, hablando del proceso de automatización, afirma que «finalmente, sólo el esfuerzo de consumir restará de las "fatigas y penas" inherentes al ciclo biológico a cuya fuerza motriz está ligada la vida humana» (2008: 144). Ella ve un paralelo entre el ritmo de las máquinas y el ritmo natural de la vida. Una sociedad calcada en este movimiento vital sería puro imperio de la necesidad y negación de lo humano. Como ella recuerda, rememorando la Antigüedad clásica y sobre todo la Grecia antigua, «todo lo que los hombres tenían en común con las otras formas de vida animal era considerado inhumano» (2008: 95). Autores como Arendt, Adorno, Foucault y Agamben concuerdan en afirmar que nuestra sociedad post Revolución Francesa cada vez más es una sociedad enfocada hacia este inhumano ${ }^{2}$.

Pero justamente el gran evento de la Modernidad es el fin de esa idea de humano y de humanidad que Arendt, de modo valiente, para algunos, y conservador, para otros, todavía intentó defender y rescatar. Desde el Romanticismo, la literatura y las artes (como todo el llamado campo de lo estético) sufrieron una profunda resignificación. Lo que quiero enfatizar es que ese cambio de paradigma fue paralelo a la entronización del proceso vital en la política. Las artes son un momento fundamental en este contexto, en la medida en que buscan justamente inscribir ese inhumano, la vida animal, la mera vida. La literatura y las artes se revolvieron contra el racionalismo y el intelectualismo humanista y iluminista y revelan al individuo como un cuerpo que sufre (Seligmann-Silva, 2005). Es esa misma literatura que dibuja y apareja al hombre moderno con un inconsciente. Todo el campo estético, por lo tanto, tiene un papel fundamental en la construcción de la era biopolítica. Si esa Modernidad es caracterizada por una hipertrofia de la esfera privada es porque ese individuo necesita todo el tiempo auto-afirmarse en un mundo donde lo público ya no le garantiza un suelo seguro. El animal laborans, para hablar de Arendt, habita la esfera privada y desconoce la pública. Él es el actor de la cultura de masas y del espectáculo del pequeño «yo», o, como Arendt escribe, de las «pequeñas cosas», del petit bonheur (2008: 61). No podemos olvidar que la literatura desde el Romanticismo tiene en la confesión y en el testimonio dos proto-fenómenos fundamentales. Rousseau con sus Confesiones (Arendt, 2008: 49), y el testimonio (religioso y jurídico) alimentaron generosamente lo que se tiene escrito en literatura

\footnotetext{
${ }^{2}$ Cf. Arendt (1988 y 2008); con relación a Adorno, cf. Seligmann-Silva (2009: 101ss.); cf. Foucault (1988: 128ss.); cf.
} Agamben (2002: 79ss). 
desde el Romanticismo. El espectáculo del «yo» es en buena parte un ersatz del «yo» pre-moderno. Él es una tentativa constante de dar forma al informe, o sea, a la identidad de este ser fracturado moderno. Ese ser es un nómada que vaga en un limbo entre el inferno de la ausencia de identidad (de lenguaje y de simbolización, que puede llevarlo a la locura) y la promesa de felicidad, cuya realización se torna su objetivo principal en la vida. La intimidad es la esfera que el individuo moderno crea como consuelo y compensación frente a la desaparición de la esfera pública. Pero esa intimidad está poblada por fuerzas que escapan de su control. Las artes son momentos de autorreflexión sobre este nuevo estado del ser humano. En ellas, esas fuerzas realizan una metamorfosis en fantasmas, monstruos, seres bifrontes, muertos-vivos, dobles idénticos y otras entidades extrañas que representan aquello que Freud bautizó con el término Unheimlich. Freud, que bebió mucho en las fuentes del Romanticismo y encontró en Schelling la mejor definición de Unheimlich, fue quien primero comprendió ese nuevo estado de cosas. Él reescribió la historia de la cultura del punto y vista de este hombre romántico dilacerado. Para ese hombre, las fuerzas que antes poblaran los mitos y asombraban las tragedias, invadieron su «yo» y necesitan ser exorcizadas.

Es esencial aquí recordar que Hannah Arendt en su estudio sobre la condición humana reserva largos pasajes para tratar de la labor y del trabajo. Ella ve a la sociedad moderna como siendo correspondiente al triunfo de la labor como forma de perpetuación de una vida inhumana, sin la preocupación con a durabilidad y con la obsesión por la longevidad. El mundo ideal de Aristóteles -y de Arendt- es el de una vida encima y más allá de la labor. La vida pública auténtica sólo puede existir después de la resolución de sus necesidades, pero aquel que queda solo en el universo de esas necesidades es como un esclavo y está al lado de un concepto clásico de humanidad. El esclavo desconoce la libertad y, por lo tanto, la vida política. Lo terrible en esa visión de Arendt es que la sociedad automatizada, que estaría ahora cada vez más libre para dedicarse a la esfera pública, en vez de eso parece que se arrastra en la esfera privada del consumismo. Al mismo tiempo, la política estaría limitándose a la administración, a la burocracia y al gobierno de nadie. En este punto Agamben no concuerda con Arendt al reintroducir, a pesar de Foucault, la idea de poder soberano en el cuadro de la teoría política actual. Pero Arendt, a su vez, recuerda que en la Antigüedad las ciudades-estado griegas, con su esfera política vislumbrada por pocos y centrada en la acción y en el discurso, se diferenciaba claramente de la cultura política de la civilización persa, marcada por el despotismo y por el automatismo de las masas (2008: 53). «El ser político, el vivir en una polis, significaba que todo era decidido mediante palabras y persuasión, y no a través de fuerza o violencia. Para los griegos, forzar a alguien mediante violencia, ordenar en vez de persuadir, eran modos pre-políticos de lidiar con las personas, típicos de la vida fuera de la polis, característicos del hogar y de la vida en familia, en la cual el jefe de la casa imperaba con poderes incontestables y despóticos, o de la vida en los Imperios bárbaros de Asia, cuyo despotismo era frecuentemente comparado a la organización doméstica» (2008: 36) La política, que se da vía acción (praxis) y discurso (lexis) se opone a la violencia, que es cambiante y no puede tener grandeza (2008: 35$)$. 


\section{La ficción-científica}

Juntando a la visión arendtiana de la historia de la política que se reduce al pensamiento economicista, estadístico y se enfoca en la reproducción de la vida (Arendt, 2008: 52ss.) con la idea de un poder soberano violento que se reproduce en medio al vacío de la esfera pública, podemos fácilmente reconocer un escenario que nos es familiar de muchas obras de ficción científica. En esas historias muchas veces o multitudes realizan trabajos mecánicos, como en la película Metropolis (Fritz Lang, 1926), o lo hacen robots, como en Yo robot (Alex Proias, 2004, basado en el libro de Isaac Asimov) y en Los sustitutos (Jonathan Mostow, 2009). En ambos casos los humanos están desprovistos de toda posibilidad de acción y de intervención en una esfera pública, que simplemente o no existe, o ha sido reducida al espectáculo de la farsa. Esos hombres pueden ser vistos como el «hombre socializado» que Arendt vislumbra en la visión de mundo de Marx (2008: 52), siendo que para ella, vale recordar, también la moderna idea de sociedad y de social es un fruto de la hipertrofia de la esfera privada y del modo de pensar biológico. La sociedad de masas no tiene lugar para a acción, sino sólo para el control de los comportamientos (2008: 50). Sus miembros son autómatas y no humanos. En esa sociedad también, donde la política es administración de la vida, no existe lo que Walter Benjamin llamó tradición y Arendt busca de permanencia por medio de la vita activa del ciudadano (2008: 29). A los miembros de la masa quedó sólo el anhelo por el consumo y por su longevidad. Ellos están reducidos a una igualdad que también los descarta de toda vida política, que sólo existe en la confrontación de las diferencias (2008: 16). En suma, nuestra sociedad de las tiendas de marca y etiquetas es el propio cadáver de la política.

Recuerdo aquí el género ficción científica, que tiene sus orígenes en obras como Frankenstein or the Modern Prometheus de Mary Shelley, de 1817, en los cuentos de E. T. A. Hoffman, con sus personas autómatas que también evidenciaban una crisis de los límites del humano, y en Dr. Jeckyll and Mr. Hyde, de 1886, de R. L. Stevenson, también debido al hecho de que Arendt escribió su ensayo sobre la condición humana en los años 1950, por lo tanto en plena Guerra Fría y ante la amenaza constante de aniquilación de la humanidad. La ficción científica (que tiene muchos vasos comunicantes con el género terror) tiene como una de sus principales características la reflexión sobre el lado distópico de la sociedad de masas. Ella escenifica el fracaso del pensamiento utópico, con su radical defensa del todo en detrimento de las partes, con su hipervalorización de los ideales, en detrimento de los hechos. La ficción científica presenta el individuo de-subjetivado, masacrado por la técnica y por un gobierno que controla la vida y muchas veces la propia reproducción y la muerte.

En este género vemos también a aparición de los robots y una reflexión sobre el humano. Una de las escenas más famosas de la historia de la ficción científica y del cine es parte del película genial 2001 Una odisea en el espacio (Stanley Kubrik, 1968). Esa escena a que me refiero consiste en la transformación de un hueso lanzado por un homínido - antes utilizado como palanca y arma para conquistar a otra tribu de homínidos- que, al rodar en el aire, de repente se transforma en una futurística estación espacial. El mensaje aquí es claro, entre la invención de la palanca-arma y la conquista del espacio hay sólo una cuestión de tiempo. La técnica es teleológica. Dentro de nuestra 
visión judaico-cristiana, ella es también uno de los definidores de nuestro estar en el mundo desde la «Caída». La técnica vislumbra reducir las penas del trabajo. Ella trae invenciones que nos liberan de las tareas más duras. En este sentido, el Golem de la tradición judaica sería un perfecto antecesor del sueño del robot que hace las tareas domésticas, como vemos en dibujos animados y en películas (recordemos el «clásico»Los Supersónicos y, más recientemente, la película con Robin Williams El hombre bicentenario [Chris Columbus, 1999], basada en un relato de Isaac Asimov). La idea de trabajo manual como trabajo envilecedor, humillante, no es superada en la Modernidad. Hoy tenemos todo un debate sobre los inmigrantes, en el llamado Primer Mundo. Esas personas muchas veces son tratadas como «ciudadanos de segunda categoría» o incluso como personas sin derecho a la ciudadanía que radicalizan la situación del hombre moderno y su estar en el limbo. Son ellos los responsables de las tareas más duras y que eran reservadas a los esclavos en la Antigüedad. Ese importante tema biopolítico puede ser articulado a la figura del Golem. Él representaría una especie de criado o esclavo «perfecto» ya que no sería una persona, no tendría un alma humana. Recordemos además que el debate sobre la existencia o no de alma en las poblaciones no europeas fue uno de los leimotivs de la era esclavocrata. Pero esta idea moderna del Golem fámulo o robot, sin embargo, es evidentemente fruto de las mentes modernas y no formaba parte de la tradición mística judaica (cf. Seligmann-Silva, 2005a).

\section{El robot como nuevo Prometeo}

Fue Karel Capek (1890-1938), en su pieza RUR (que significa la abreviación del nombre de una firma: Reson's Universal Robots), de 1920, quien introdujo el término «robot» en la cultura moderna. La palabra viene del término checo robota utilizado para expresar el trabajo servil, duro, en fin, la labor. Capek, inspirado en la tradición del Golem de Praga, también escribe su ficción científica a partir de la experiencia de la Primera Guerra Mundial, que reveló la fuerza destructiva de la técnica. En esa obra el robot-Golem es una metonimia de la técnica y, por lo tanto, una especie de antecesor de la palanca-arma del película de Kubrik. Ahí, los robots se revelan como buenos descendentes de Adán, Prometeo y Mefisto. Es digno de hacer notar el modo como el director de la fábrica RUR, el señor Harry Domin se refiere a los operarios robots: «fabricar operarios artificiales es la misma cosa que fabricar motores a diesel. La producción debe ser simplificada al máximo y el producto el mejor posible. [...] el mejor trabajador posible [es] aquel que cuesta más barato. Aquel que exige menos. El joven Reson [...] al simplificar el hombre, creó el robot. [...] los robots no son hombres. Desde el punto de vista mecánico, ellos son más perfectos del que nosotros, ellos poseen una impresionante inteligencia racional, pero ellos no poseen alma. Usted ve [...], el producto Reson es técnicamente superior al producto de la naturaleza» (Capek, 1997: 24). En la pieza, Helene Glory es una activista de la Liga de la Humanidad (1997: 32; recordemos que en 1918 fue creada a Liga de las Naciones) que lucha para dar conciencia a los robots. En la historia ella es presentada a Sylla, un robot, y no cree que se trate de una persona. Esta pasaje se torna después tópico en las ficciones científicas, y reaparece, 
por ejemplo en Blade Runner (Ridley Scott, 1982) con relación a la replicante Rachel. La idea es que el ser humano se tornó un creador tan perfecto como Dios. Sus copias son ahora originales. La técnica se emancipa, así como el hombre, creación de Dios, se rebeló y se emancipó de él, hasta el punto de matarlo. Pero Domin, evidentemente, como su nombre indica, quiere mantener los robots/operarios bajo control. Para probar a Héléne Glory que Sylla es un robot él ordena que ella sea disecada. Héléne se escandaliza ante esta propuesta de «matar» a Sylla, a lo que Domin responde que «No matamos máquinas» (1997: 27). Claro, no se mata máquinas, justamente porque no consideramos que ellas tengan alma o vida. Ellas no son personas: «Un robot es lo que existe de más opuesto al hombre» (1997: 34). El Golem, en la tradición judaica, tampoco puede ser asesinado, porque él no es una persona, sino que tiene un estatuto de cosa. Robots y Golems son avatares de aquello que los romanos antiguos, como recuerda Agamben, denominaron homo sacer, seres simplemente matables pero sin que su destrucción fuera considerada un asesinato. El ingeniero de la RUR, Fabry (un homo faber, creador del animal laborans...), defiende que los humanos son máquinas imperfectas que deben ser sustituidas. Para él, «la naturaleza no tenía ninguna noción de eficiencia. Desde el punto de vista de la técnica, la infancia es, evidentemente, tiempo perdido. En suma, inútil. Un desperdicio inaceptable de tiempo» (1997: 34). Héléne Glory, que quiere liberar a los robots y tratarlos «como si ellos fueran hombres» (1997: 35), actúa como una perfecta defensora de los derechos de los trabajadores. Ella ha desarrollado compasión por aquello que debería estar excluido del círculo compasivo. En un gesto irónico con relación a esa biopolítica de la vida calcada en el código de protección de la vida, Capek hace que los empresarios de la RUR declararen su interés en entrar a la Liga de la Humanidad, ya que, al final, también ellos tienen interés en defender a las máquinas. Él ironiza también la idea de una sociedad automatizada que podrá suplir plenamente las necesidades de todos - y dejar a todos al mismo tiempo desempleados-: «cada uno tomará aquello que necesita. No habrá más miseria. Sin duda que ellos no tendrán más trabajo, pero el trabajo no existirá más. Todo será hecho por máquinas vivientes. El hombre podrá consagrarse a lo que ama. Él vivirá sólo para perfeccionarse» (1997: 38). Vemos aquí la situación explorada por Arendt de la sociedad automatizada post-trabajo, que se hundirá en la futilidad. En Capek se trata también de la reversión de la «Caída»: el hombre no necesitará más «romperse por un pedazo de pan», afirma Domin. A lo que el arquitecto Alquist contesta, recordando la «virtud del trabajo» y la servidumbre y humildad - conceptos, como mostró Arendt, caros para la Modernidad-. Pero Domin insiste en su visión paradisíaca de la sociedad robotizada: «A partir de ahora Adán no comerá más su pan a costa del sudor de su frente, él no conocerá ni la sed, ni la hambre, ni la fatiga, ni la humillación, él regresará al paraíso donde la mano del Señor lo alimentará. Él será libre y soberano. [...] Él será, en fin, el maestro de la creación» (1997: 38). Domin defiende una sociedad totalmente emancipada de la necesidad. Es como si la especie descendiente de Adán se librase de su origen bajo, de la tierra (adama) que nos constituyó originalmente. Domin representa el triunfo del homo faber. Como Arendt notó, «sólo el homo faber se porta como amo y señor de toda la tierra. Como su productividad era vista a la imagen de un Dios Creador [...], la productividad humana, por definición, resultaría fatalmente en una revuelta prometeica, ya que sólo puede construir un mundo 
humano después de destruir parte de la naturaleza creada por Dios» (2008: 152). Capek muestra esa rebelión dándose en la generación que fue posterior a la de los hombres, los robots. Por lo tanto, el sueño prometeico de Domin es sólo una parte de la verdad, ya que ese paraíso tecnológico tiene sus pies de barro. El Dr. Hallmeier, director del Instituto de Psicopedagogía de Robots, recuerda a Glory que los robots no sienten placer, no tiene gustos, no sonríen, en suma, no poseen voluntad, pasión, historia y no sienten amor u odio. Ellos son, en su pura materia, cosas. Pero el error que de cierto modo desencadena la autoconciencia de los robots y los transforma en seres con voluntad y por lo tanto, capaces de rebelarse, es la idea del Dr. Gall, director del departamento de investigaciones fisiológicas de la RUR, de introducir en los robots la capacidad de sentir dolor y de sufrir. Su objetivo era absolutamente económico: «prevenir contra la degradación del material» (1997: 36). A partir de la capacidad de sentir dolor los robots desarrollan otros sentimientos y acaban rebelándose contra los hombres, en una perfecta revolución aniquiladora ${ }^{3}$. El monstruo creado por Frankenstein, así como la computadora HAL, de la mencionada película de Kubrik, son figuras clásicas dentro de esta tradición de rebelión de la técnica que Capek muestra aquí. La palanca se manifiesta como arma que ataca a su propio creador, o como Capek formula en boca de uno de sus personajes: «Si transformamos piedras en hombres, luego seremos apedreados» (1997: 77). Domin lamenta el fracaso de su sueño de «liberar a la humanidad de la esclavitud. Del trabajo degradante y duro, del corvée sucio que mataba. [...] Yo quería que el hombre se tornase el maestro del universo y que él no viviese sólo para ganar el pan. Yo quería que él fuera otra cosa más allá de un sencillo ser embrutecido ante una máquina que ni siquiera le pertenece a él. Oh, yo detesto la humillación y el dolor, yo detesto la miseria» (1997: 73). Aquí Capek presenta a la humanidad como reducida a la miseria y al esfuerzo del trabajo alienado, una visión típica de su época. Pero él muestra también de modo irónico cómo la sociedad automatizada y libre del trabajo sólo profundizará la miseria y no significará la concretización de la promesa del retorno al paraíso por el medio de la tecnología. Al final del drama, dos robots, Héléne y Primus, muestran pasión y compasión uno por el otro. Alquist concluye que ellos podrán reproducirse. La pieza se cierra con Alquist releyendo el capítulo de la creación en el Génesis. Después él afirma que la vida renace, «su raíz se lanzará en el desierto. [...] La vida no acabará. No acabará. No acabará» (1997: 105). Esas son las últimas palabras de este texto paradigmático fundamental. Se trata de la supervivencia, de la continuación de la vida que es presentada de modo enfático, en esa gran obra de Capek. Él ve una nueva especie que sustituirá a la humana: como los hombres vinieron después de los monos (y estos después de los hombres, en El planeta de los monos [Franklin James Schaffner, 1968]). Los robots cuando se transformaron en seres autoconscientes preguntan a Alquist cuál es el secreto de la vida de los robots —así como Roy Batty, el líder de los replicantes, lo hará en Blade Runner-. Alquist dice que la receta de la construcción de los robots se perdió, pero la respuesta que la pieza da es la propia capacidad de sentir emociones. Ese fin puede haber inspirado el final de la primera película

\footnotetext{
${ }^{3}$ Aquí Capek retoma un credo central de la Modernidad, a saber, la idea de que la compasión es la marca distintiva de la humanidad. Esa tesis fue defendida de modo particularmente radical por Rousseau y, como Hannah Arendt lo mostró (1988), esa noción de compasión después estuvo en el centro de la construcción de la política como agenciamento de las necesidades. Regresaremos a esa cuestión de la compasión más abajo.
} 


\section{Márcio Seligmann-Silva}

de la serie Jurassic Park (Steven Spielberg, 1993), cuando los dinosauros, que habían sido producidos por ingeniería genética con el cuidado de ser sólo masculinos, para que no se reprodujeran de modo descontrolado, comienzan a transformarse en hermafroditas y a reproducirse. La vida, la mera vida, es la lucha por la reproducción de sí y la ficción científica es un género que se especializó en explorar esa fuerza germinante y destructora de la vida en la su interfaz con la técnica. Él explora la ambigüedad de la tecnología, pero también a cuestión primordial: ¿quiénes somos nosotros?

\section{Intermezzo kafkiano}

Un conterráneo de Capek, Franz Kafka, como sabemos, fue tal vez uno de los que más fue a fondo en esa interrogación sobre el hombre moderno. Capek, Kafka y Freud, tres grandes solicitantes de este hombre y tres testigos del fin del Imperio Austro-Húngaro, se dieron cuenta como pocos del significado de los cambios biopolíticos de su época. Recuerdo aquí sólo de un corto, pero impactante texto de Kafka. Si es evidente que Kafka no escribió propiamente ficción científica, por otro lado él fue uno de los autores que más lejos fue en la presentación de los nuevos paisajes biopolíticos del siglo Xx. Recordemos, por ejemplo, el texto «Ein altes Blatt» («Un viejo folio»), del volumen Un médico rural (publicado en 1920). Esa corta narración trata de una pequeña ciudad que fue invadida por «nómadas del norte». Asistimos entonces — como es frecuente en Kafka- a la operación de animalización de los hombres, o del despojo de esos animales avergonzados de su tenue ropaje humano. En el texto, esos bárbaros del norte comen carne cruda —así como sus caballos también lo hacen-. Ellos muchas veces comparten el mismo pedazo de carne que devoran juntos. Y si una vaca viva les es lanzada, bárbaros y caballos a deambulan locamente con sus dientes afilados, de un modo que sólo Eurípides había antes descrito en sus Bacantes, refriéndose al frenesí de las tebanas hechizadas por Dionisos. Esa narrativa kafkiana cuenta la historia de la disolución de las ciudades realizada por la inoculación de esa invasión «animal» (bien dionisíaca también). Pero ella es más que eso. Ella presenta el rey impotente en el palacio imperial como una metáfora de la crisis en el poder soberano que, a su vez, para existir, necesitará domar a la «vida natural» (zoe), la «vida desnuda», como escribió otro contemporáneo de Kafka, Walter Benjamin. (Benjamin, 1974) Al tratar de la vida animal, Kafka toca en la crisis de la soberanía y de la nuestra autoimagen. Esas dos crisis son puestas lado a lado. Él muestra al animal en nosotros, como Freud y, antes de él, Darwin lo harían. Kafka muestra también un poder amorfo, teóricamente el monopolizador de la violencia, que intenta administrar esa vida desnuda que se le escapa (ante la cual Penteo y Cadmo, abuelo de Dionisos, también sucumbieron por no saber venerar y sacrificar a los dioses). El final de la narración muestra a la ciudad siendo tragada por los bárbaros: «El palacio imperial atrajo a los nómadas pero no es capaz de expulsarlos. El portón permanece cerrado. [...] A nosotros, artesanos y comerciantes, fue confiada la salvación de la patria; pero no estamos a la altura de una tarea de esas, ni jamás nos vanagloriamos de estar. Es un equívoco y por causa de él vamos a arruinarnos». Ese portón cerrado, una figura muy frecuente en los textos de Kafka, simboliza también la ley y su tendencia a excluir al individuo. La ley 
es un muro que excluye al individuo. Ese individuo está preso sólo a su ínfima intimidad. El Estado lo excluye y a ciudades, en vez de protegerlo, lo apresan y lo quieren controlar. Town, como recuerda Arendt, en inglés, originalmente, como el alemán Zaun, significa cerca (cf. Arendt, 2008: 73) Como en la obra de Capek, también al leer Kafka nos preguntamos, pero al final, ¿qué es el ser humano?

\section{La muerte de la compasión}

Evidentemente, esa cuestión ha tenido innumerables respuestas, pero desde la época de Rousseau existe una tendencia a atribuir al proceso civilizatorio — en el sentido de dominio de la vida urbana moderna y del esclarecimiento- una reducción de la capacidad de compasión. En este sentido, pensando en la pieza de Capek, es como si poco a poco los seres humanos se desprendieran de las emociones, transformándose en máquinas, autómatas sin voluntad (nuevamente, recordemos Metrópolis de Lang), en la misma medida en que las máquinas poco a poco van ganando capacidad de trabajar, de pensar y hasta de sentir por nosotros. En este sentido es importante recordar a Jules Verne, que en su novela de 1863 no publicada en vida por su editor Pierre-Jules Hetzel, hizo un panorama de Paris au $X X^{e}$ siècle que presenta una sociedad totalmente dominada por la técnica y por la lógica capitalista. En esta sociedad no existe espacio para las artes, a no ser las que hacen alabanzas autoelogiosas aquel mundo. El futuro aparece como limpio y organizado, sin lugar para las emociones y para relaciones no lucrativas. Se trata de una explicitación crítica de aquello que más tarde Adorno y Horkheimer llamarían dialéctica del Esclarecimiento. En el mundo futuro de esta obra de Verne el Bildungsroman del hombre moderno ya no es posible. El arte, que en el modelo goetheano servía de «desvío formador», está sofocado en esta sociedad perfectamente burocratizada. El hombre está reducido a mero capital humano. La técnica y el lucro guían lo cotidiano de hombres tristes, verdaderos autómatas, con una vida emocional y sexual desérticas. La sociedad es comparada a una enorme prisión (Verne, 1994: 72). Michel Duffrénoy, el protagonista, es un verdadero ET en su sociedad que desprecia todo lo que tiene que ver con cultura: él es profesor de latín y se encuentra más y más sin un público. En este mundo de Verne es como si el hombre egoísta, que Rousseau viera triunfar en la sociedad urbana de su época, hubiese conseguido extirpar la última gota de piedad de la faz de la tierra. (Verne, 1994: 154) La narrativa es del tipo que después se tornó tradicional y es bien conocida para los lectores de George Orwell y Aldous Huxley, o para los que vieron Matrix (Lana y Andy Wachowski, 1999): ella cuenta la historia de un individuo que consigue mantener su autonomía en medio de la aniquilación de la individualidad. Se trata de una alegoría del individuo moderno sofocado en la sociedad cosificada que lo aliena. Es memorable el hecho de que editor de Verne, Hetzel, sintió en este libro un cierto aire de los escritos de Fourier (Verne, 1994: 13).

Si es en la ficción científica donde este rostro distópico de la tradición utópica viene a la luz con más intensidad, o sea, justamente en el género literario que explora las relaciones entre el hombre y la técnica, por otro lado, no es menos verdad que existe una relación profunda entre la propia ficción científica y el cine. Es como si la técnica cinematográfica permitiese un clavado todavía mayor en las 
potencialidades distópicas de la técnica que este género encierra. La ambigüedad de la técnica es desdoblada en el dispositivo cinematográfico. Este se transforma en verdadero bisturí, para recordar otra imagen de Benjamin, aplicada por él para describir al cine ${ }^{4}$, que penetra las carnes del hombre moderno, virando el envés de su piel que cada vez más es mero ropaje para una pseudo-individualidad. Permítanme entonces concluir hablando de una película que me parece muy propicia para discutir el tema en pauta.

\section{La última frontera cae: cultura y/o naturaleza}

Blade Runner es una obra fundamental para estudiar esa capacidad de la película de ficción científica de presentar y testimoniar al hombre y lo inhumano en la era biopolítica. Ya el letrero de apertura nos lanza en plena era de la gestión de la vida desnuda y, recordando a Agamben, de control y aniquilación del homo sacer. Citemos esto:

Early in the 21st Century, THE TYRELL CORPORATION advanced Robot evolution into the NEXUS phase - a being virtually identical to a human - known as a replicant. The NEXUS 6 Replicants were superior in strength and agility, and at least equal in intelligence, to the genetic engineers who created them.

Replicants were used Off-world as slave labor, in the hazardous exploration and colonization of other planets.

After a bloody mutiny by a NEXUS 6 combat team in an Off-world colony, Replicants were declared illegal on earth — under penalty of death - Special police squads - BLADE RUNNER UNITS — had orders to shoot to kill, upon detection, any trespassing Replicants.

This was not called execution. It was called retirement.

También en esa obra las víctimas no humanas no son asesinadas, ya que matarlas significa sólo «jubilarlas». Las dos primeras imágenes del película son emblemáticas: la ciudad (Los Angeles en 2019) y, luego enseguida, un enorme ojo azul en close. Se trata de la misma polaridad que vimos arriba entre la polis y la esfera privada. Los Angeles es retratada como una mezcla de ciudades, supertecnológica e infierno industrial con sus chimeneas que escupen fuego. La Tierra en la película es presentada como un local decadente, donde quedan sólo los menos capaces, el resto. Los habitantes de Los Angeles son casi todos inmigrantes. El gran ojo azul que aparece rápidamente, después de la primera imagen de Los Angeles, sólo después descubrimos, es de Roy Batty, el líder de los replicantes que se rebelan. Los Angeles y sus chimeneas que escupen fuego se reflejan en este ojo. El ojo representa aquí la puerta para la intimidad de Roy, un ser poseído por el deseo de longevidad y odio con relación a los seres humanos. O sea: ya no existe lugar para la esfera pública, la ciudad es una ruina post-industrial que consume sus moradores reducidos a ratones $\mathrm{y}$, al mismo tiempo, tampoco existe la esfera privada de la individualidad: los seres replicantes, así como los inmigrantes y el propio Deckard (el protagonista) poseen todos identidades postizas, injertos de vida.

La primera escena de la película también es emblemática. Ella muestra un policía aplicando una prueba a alguien. Se trata de la prueba Voight-Kampff: una especie de detector de mentiras del futuro,

\footnotetext{
${ }^{4}$ El cine, para Benjamin, es una técnica que penetra «profundamente las vísceras de esa realidad» como el bisturí de un cirujano (Benjamin, 1985: 187).
} 
utilizada para descubrir a los replicantes. Esa máquina sería un dispositivo biométrico que separa a los humanos de los replicantes. Si el antiguo detector de mentiras pretendía desvendar las emociones humanas, o sea, revelar nuestra intimidad que se tornó el único patrimonio y tabla de salvación en la era biopolítica - y por eso mismo, es ostensivamente presentada-, el aparato Voight-Kampff es el correspondiente en la era de la indiferenciación entre humanos y robots biológicos. Este aparato mide las reacciones emocionales del entrevistado ante situaciones de dolor que provocan compasión. Como los replicantes tendrían un lado emocional atrofiado (de segundo orden, una excrecencia en robots que deberían simplemente trabajar), esta prueba, que enfoca en las reacciones de micro-movimientos de la pupila (exploración nuevamente de la idea clásica del ojo como puerta del alma) los denunciaría. Pero en la medida en que se necesita un aparato tan sofisticado para separar a los humanos de los artefactos, la trama de Blade Runner ya apunta hacia la efectiva no diferenciación posible entre robots y humanos. A lo largo del película también se insinúa que el protagonista, Rick Deckard, representado por Harrison Ford, el Blade Runner que debe matar a cinco replicantes, también seria él mismo un ser artificial. Rachel, por quien él se apasiona, sería una replicante sin fecha de validad precisa, idéntica, por lo tanto, a los demás humanos. En varios momentos se afirma que en la verdad hombres y replicantes están sometidos a las mismas leyes de la naturaleza, enturbiándose así las fronteras entre lo natural y lo artificial. En un determinado momento un policía, Gaff, dice a Deckard con relación a Rachel: «It's too bad she won't live. But then again, who does?». J. F. Sebastian, el diseñador genético de Tyrell Corporation, a su vez, sufre de progeria, o sea, de envejecimiento precoz. Por eso se identifica con los replicantes en su lucha por la longevidad. Sebastian, con su progeria, es un retrato de la humanidad reducida a su cuerpo biológico. Él vive rodeado de animóides y pequeños replicantes que él diseñó para ser sus amigos. Si vemos que el Romanticismo representó un primer gran giro que lanzó al hombre hacia adentro del espacio cada vez más dominado por la biopolítica, ahora, con la profundización del dominio de la lógica biológica en la fase de la sintetización de los seres humanos y de la vida, paralela al triunfo de la globalización como homogeneización y aniquilamiento de las diferencias en términos internacionales, pues bien, en ese segundo giro biológico dejamos de diferenciar algo que hasta ahora fue absolutamente importante, o sea, la separación entre el campo de la naturaleza y el de la cultura. La rebelión de los replicantes en la película de Ridley Scott tiene como fin no sólo la liberación del trabajo esclavo, sino la conquista de la longevidad. Como nosotros, esos replicantes luchan por su longevidad, por la perpetuación de la vida. La prueba de empatía también toca en otro punto delicado para pensar en la profundización de ciertas marcas de la era de la política como administración de la vida. Para Rousseau, la característica de la humanidad era la compasión (Rousseau, 1976: 43s.; 1964: 153s.). La prueba compasiva muestra que los replicantes son marcados por conflictos emocionales cuando son encarados con situaciones de dolor. Por otro lado, los cuatro replicantes rebeldes poseen una relación de grupo muy fuerte y calcada en una compasión mutua. Deckart, a su vez, se apasiona por una replicante, Rachel, y tiene compasión por los que él mata en su misión de blade runner, comportándose, por lo tanto, como si de hecho fuera uno de ellos. Deckart, además, como Michel Duffrénoy en la novela de Verne que vimos arriba, tiene una vida que parece un desierto emocional y 
su pasatiempo predilecto es ahogarse en whisky. Pero sólo tiene sentido fabricar robots biológicos para la labor ardua si no tenemos compasión para con ellos. La propia Rachel, cuando pasa por la prueba Voight-Kampff, se muestra una vegana, o sea, una especie de máximo que la humanidad logró hoy en su escala compasiva. Ella afirma que si recibiera de regalo una cartera de cuero la devolvería y denunciaría la persona que se la regaló. Pero eso no impide a Rachel matar a uno de los replicantes. O sea, compasión y capacidad de exterminio no son incompatibles. El líder de los replicantes, Roy Batty, a pesar de ser presentado como un frio asesino, está locamente apasionado por su vida y por la replicante Pris. En la famosa secuencia final de la película, que culmina con la frase «Time to die» y con su muerte, se proyecta en Roy la imagen de un Cristo en su pasión. Roy clava en su mano un enorme clavo, semejante al que acostumbramos ver en la iconología de las imágenes de Cristo en la cruz. Es como si sólo el dolor pudiese mantenerlo por más tiempo en vida. Recordando el drama de Capek, el dolor (y la compasión) está en el origen de la hominización ${ }^{5}$. Roy se presenta también como testigo de terribles violencias y como un superviviente de la explotación de replicantes. Él se torna una figura digna de compasión, así como Rachel y otros personajes, humanos o no, de la película. El panorama biopolítico de Blade Runner presenta una humanidad siendo consumida por su gadgets. En determinado momento Bela Pris dijo a Sebastian: «I think, Sebastian, therefore I am». En la oficina del todopoderoso dueño de Tyrell vemos un búho que también es un animoide. Este animal-robot, símbolo del saber, también sirve aquí para alegorizar el derretimiento de las fronteras entre lo natural y lo artificial, entre la razón, el ingenio y el instinto. Al final, la técnica es mero prolongamiento de nuestros cuerpos y vislumbra nuestra supervivencia - incluso aunque pueda llevar a nuestra destrucción-.

Sin poder distinguir entre original y copia, el sentido de lo humano se pierde y un nuevo giro cualitativo es dado en el proceso que Walter Benjamin bautizó como una ruptura con la tradición y que habría sido desencadenado por la era tecnológica de la reproductibilidad de imágenes (Benjamin, 1985: 169). En la era de la reproductibilidad de la vida todo indica que la tradición se disuelve y nada más puede garantizar lo que un día llamamos nuestra humanidad. Si la reproducción técnica rompe los lazos con el pasado cultural, la sintetización y la reproducción como replicación de la vida significan una despedida de la tradición que nos fue legada por millones de años de inscripción genética. No por casualidad en Blade Runner, tanto los replicantes como el policía Deckart tienen una verdadera manía de coleccionar fotos que serían la única garantía de sus historias y de la existencia de un pasado que no sería mero implante hecho en sus cerebros. La fotografía, que para Benjamin significa la despedida de la tradición, funciona aquí como único rastro y relación con la historia. Hombres y robots biológicos

\footnotetext{
${ }^{5}$ Cabe recordar que para Nietzsche las figuras de Dionisos-Zagreo y de Orfeo (que son identificadas en Nietzsche) remiten a lo amorfo (no-apolíneo), la naturaleza salvaje que destruye y renace de dentro del hombre, bajo la figura de Zagreo como «salvaje comedor de carne». El renacimiento de Dionisos simbolizaría justamente la superación del principio de individualización, del dolor que está en el origen de la individualización y que la tragedia curaría. Nietzsche también condena la tradición de la mnemotécnica, cuyo lema él deriva del siguiente modo: «¿Cómo hacer en el animal-hombre una memoria? ¿Cómo grabar algo indeleble en esa inteligencia enfocado hacia el instante, medio obtuso, medio liviano, en esa encarnación del olvido? [...] Se graba algo al fuego, para que quede en la memoria: tan sólo lo que no cesa de causar dolor queda en la memoria» (Nietzsche, 1988: 295; correspondiendo a Nietzsche, 1998: 50).
} 
se protegen con esas imágenes para no sentirse chupados por el vacío de identidad y reducidos a meras computadoras sobre dos piernas con fecha de vencimiento. (¿Será que eso tiene algo en común con nuestra manía por fotos/imágenes en la era digital?) El Estado aparece en la película sólo en su faz policial de control de esos gadgets rebeldes. Toda la esfera pública está dominada por enormes anuncios brillantes publicitarios, que profundizan la sensación de que no existe tampoco diferencia entre las imágenes y la realidad.

Ese análisis de la ficción científica nos permite retornar a Hanna Arendt, que, pocos acostumbran recordar, abrió su ensayo sobre La condición humana resaltando tanto la capacidad de la ficción científica de prever los desdoblamientos de la técnica, como también lamentando la poca respetabilidad pública de este género (Arendt, 2008: 10). Ella también ve en este género un importante «vehículo de los sentimientos y deseos de las masas»y, por lo tanto, como una entrada para estudiar tanto el presente como para especular sobre nuestro porvenir. Su ensayo sobre la condición humana fue marcado por el lanzamiento de los primeros satélites que mostraron que el hombre ahora podría liberarse de aquello que siempre marcó su vida, la Tierra. Como ella escribe, ese hombre también caminaba ya hacia la sintetización de la vida y creación de lo que ella describió como «seres humanos superiores», tal vez en una alusión a los terribles experimentos eugénicos del tercer Reich. Esos hombres también sobrepasaron los cien años de vida, realizando el sueño de longevidad del animal laborans y de los replicantes de la película de Scott. Pero esa sociedad futura, Arendt especula, podrá ser marcada también por la esclavitud «no tanto de nuestras máquinas como de nuestro know-how, criaturas desprovistas de raciocinio, a la merced de cualquier artimaña técnicamente posible, por más mortífera que sea» (2008: 11). Tratando del proceso de automatización del trabajo, ella formula que lo que tenemos ante nosotros es una «sociedad de trabajadores sin trabajo, esto es, sin la única actividad que les resta. Ciertamente nada podría ser peor» (2008: 13). En cierto modo, encontramos tanto en Capek, en su obra de 1920, como en muchos otros libros y películas de ficción científica esa misma conclusión. Propongo que nos dediquemos más a leer, sea en la literatura, sea en el cine, tanto nuestros deseos utópicos como también la terrible ambigüedad de la tecnología.

São Leopoldo, 13 de septiembre del 2010.

\section{Obras citadas:}

Agamben, Giorgio (2002): Homo Sacer. O Poder soberano e a vida nua I. Belo Horizonte, UFMG. ARENDT, Hannah (1988): Da Revolução. Trad. Fernando Dídimo Vieira. São Paulo, Ática.

- (2008): A condição humana, trad. De Roberto Raposo, Rio de Janeiro: Forense Universitária, $10^{\mathrm{a}}$. Edição, 2008.

BENJAMIN, Walter (1974): «Zur Kritik der Gewalt», en Gesammelte Schriften, vol. II, Aufsätze, Essays, Vorträge. R. Tiedemann y H. Schweppenhäuser, eds. Frankfurt, Suhrkamp, pp. 179-203. (1985): Obras escolhidas, vol. I, Magia e técnica, arte e política. Trad. S. P. Rouanet. São Paulo, Brasiliense. 
118 Tropelías. Revista de Teoría de la Literatura y Literatura Comparada, 25 (2016)

Márcio Seligmann-Silva

CAPEK, Karel (1997): R.U.R. Reson's Universal Robots. Trad. Jan Rubes. La Tour de l'Aigues, Editions de l'Aube.

Foucault, Michel (1988): História da sexualidade. 1 A vontade de saber. Trad. M. T. da Costa Albuquerque y J. A. Guilhon Albuquerque. Rio de Janeiro, Graal, $15^{\mathrm{a}}$ ed.

KAFKA, Franz (1994): Gesammelte Werke in zwölf Bänden. Nach der Kritische Ausgabe. Hans-Gerd Koch, ed. Frankfurt, Fischer.

(1999): Um médico rural. Trad. M. Carone. São Paulo, Companhia das Letras.

NIETZSCHE, Friedrich (1988): Jenseits von Gut und Böse, Zur Genealogie der Moral. Eine Streitschrift, en Kritische Studienausgabe, vol. 5. Eds. G. Colli y M. Montinari. München-Berlin-New York, DTV-Walter de Gruyter.

(1998): Genealogia da Moral. Uma polémica. Trad. Paulo C. Souza. S. Paulo, Companhia das Letras.

Rousseau, Jean-Jacques (1974): Essai sur l'origine des langues. Ed. A. Kremer-Marietti. Paris, Aubier Montaigne.

(1976): Discurso sobre a origem e fundamentos da desigualdade entre os homens. Trad. M. de Campo. Mira-Sintra, Publicações Europa-América.

SEligmanN-Silva, Márcio (2005a): «Arte, dor e kátharsis, ou variações sobre a arte de pintar o grito», en $O$ local da diferença. Ensaios sobre memória, arte, literatura e tradução. São Paulo, 34.

__ (2005b): «O Golem: Entre a técnica e a magia, aquém da bioética», Remate de Males, 27/2, pp.183-195.

_ (2009): A atualidade de Walter Benjamin e de Theodor W. Adorno. Rio de Janeiro, Civilização Brasileira.

Verne, Jules (1994): Paris au XX'e siècle. Paris, Hachette. 